\title{
Governance Crisis and Democracy in Nigeria, 1999 - 2012
}

\section{Femi Omotoso PhD}

\author{
Department of Political Science \\ Ekiti State University, Ado- Ekiti \\ femot79@yahoo.co.uk
}

Doi:10.5901/mjss.2013.v4n14p125

\begin{abstract}
Democracy is adjudged the best form of government all over the world. In 1999, Nigeria joined other civilised countries by enthroning democratic political system. Consequently, this paper examines governance crisis and effects on the sustainability of democracy in the country. Adopting narrative descriptive approach, the paper notes that democracy is capable of ensuring good governance based on rule of law, accountability, and transparency among others if well managed. However, in the case of Nigeria, the paper observes that the nation has made some giant strides in its democratic journey since 1999 but the people are yet to fully reap the fruits embedded in this political system. This is as a result of challenges like corruption, ethnicity, leadership failures and other egregious national problems which combined in frustrating the sustenance of democracy in Africa's most populous nation. The paper concludes that what is needed in the country is the strengthening and building of institutions of government rather than personalisation of state authority. The institutions of government so strengthened will act as catalysts in promoting the goals of democracy and serve as bulwark against abuses.
\end{abstract}

Keywords: Nigeria, Democracy, Governance crisis and Development

\section{Introduction}

The year 1999 marked a watershed in the history of modern Nigeria, in that it ushered in what was expected to be 'enduring democracy'. Before then, the country had oscillated between civil and military rule, with the latter having the upper hand. Since 1999, however, Nigeria has been enjoying uninterrupted democratic governance. This seems unbelievable if recourse is made to the history of the country. It is this reality that informed this chapter, which subjects this period of unbroken democratic rule to critical analysis and x-rays governance and politics in the country to see the impact on societal development and citizens' participation in governance.

Ordinarily, democratic governance should, among other things, usher in societal development, inclusion and participation of citizens in governance; accountability and transparency on the part of government officials, but, can Nigerians actually say they have enjoyed dividends of democracy in the past twelve years? The paper therefore attempts to enhance our understanding of this. The paper is segmented into four different sections viz; the introduction, Nigerian democracy in perspective, a review of governance and democracy since 1999 and conclusion.

\section{Nigerian Democracy in Perspective}

Officially, Nigeria became a state on January 1, 1914 after the amalgamation of the southern and northern protectorates. After many years of colonial rule, the country became independent on $1^{\text {st }}$ October, 1960 . The first republic was shortlived, ending with the coup d'état of January 15, 1966. Between this period and October 1, 1979 when civilian rule returned, the country was administered by the military. The return to democratic rule ushered in a federal constitution characterized by multipartism, independence of judiciary, separation of powers, among other features. This experience was, however, truncated again by the military precisely on December 31,1983 , and the country remained firmly under military rule until May 29, 1999 when another democratic experiment began.

This time, however, the military did not willingly relinquish power as in 1979, but for so many reasons which included the crisis generated by the annulment of the June 12, 1993 presidential election believed to have been won by late Chief M.K.O Abiola. This singular issue shook the nation to its foundation. The crisis precipitated by Ibrahim Babangida, the military president who "dribbled" Nigerians through long-drawn grandiose and elaborate but dubious and cunning policies and programmes designed mainly for self-perpetuation in power and ended up annulling an election 
adjudged the freest ever. The problem spiralled on under the tyrannical and despotic regime of General Sani Abacha who rail-roaded himself into power after Babangida had been forced to "step aside." In the circumstances, Nigerians were determined more than ever to chase the military out of power. The deep commitment of the people for the enthronement of democratic rule paid off as the military under the leadership of General Abdulsalam Abubakar, who ascended into power upon the sudden death of Abacha, willingly relinquished power.

However, despite the determination of the military to cede power, the organisation's leadership could not really trust any civilian with power particularly from the South-West to where the presidency seemed to have been 'zoned'. To resolve this dilemma, Chief Olusegun Obasanjo, a former military head of state who had earlier been jailed by Abacha's regime, was quickly given presidential pardon and drafted into the presidential race as the candidate of one of the three registered political parties, the Peoples Democratic Party (PDP). He emerged as the winner in the general election and was sworn in as the second democratically elected president of the Federal Republic of Nigeria on May 29, 1999. At inauguration, Obasanjo appeared well prepared for the tasks ahead since he was not a stranger to power. In 1979, he was the military head of state that handed over power to Alhaji Shehu Shagari as the first elected president. Obasanjo bemoaned the situation he met the nation in, particularly as it related to governance in areas like economy, education, security, infrastructure, and so forth. According to him:

\begin{abstract}
We experienced in the last decade and half, particularly in the last regime but one, persistent deterioration in the quality of our governance, leading to instability and the weakening of all public institutions. Good men were shunned and kept away from government while those who should be kept away were drawn near. Relations between men and women who had been friends for many decades and between communities that had lived together in peace for many generations became very bitter because of the actions or inactions of government. The citizens developed distrust in government, and because promises made for the improvement of the conditions of the people were not kept, all statements by government met with cynicism. The impact of official corruption is so rampant and has earned Nigeria a very bad image at home and abroad. Besides, it has distorted and retrogressed development. Our infrastructures NEPA, NITEL, Roads, Railways, Education, Housing and other Social Services were allowed to decay and collapse. Our country has thus been through one of its darkest periods. All these have brought the nation to a situation of chaos and near despair. This is the challenge before us. Fellow Nigerians, let us rise as one, to face the tasks ahead and turn this daunting scene into opportunities in a New Dawn. Let us make this the beginning of a genuine Renaissance. (Obasanjo, cited in The Guardian, May 30)
\end{abstract}

He gave his commitment to put things right and make Nigerians to see the benefits of democratic rule.

This chapter therefore examines the extent to which governance and democracy have benefited the people between 1999 and 2012.

\title{
3. A Review of Governance and Democracy Since 1999
}

On balance, Chief Olusegun Obasanjo has impacted more on the Nigerian political space and indeed the country's democracy than any Nigerian dead or alive. The fulcrum of governance and democracy in Nigeria within the period under review without any doubt is the foundation laid by the Obasanjo administration. As noted earlier, Obasanjo showed commitment towards bringing the country on the right track. As such, he initiated so many policies, programmes and reforms which were geared towards the growth and development of the country. Some of the reforms are:

- Monetisation Policy

- National Economic Empowerment Development Strategies (NEEDS)

- Economic and Financial Crimes Commission (EFCC)

- Independent Corrupt Practices and Other Related Offences Commission (ICPC)

- Banking Reforms

- Revitalisation of the National Food and Drug Administration (NAFDAC)

- Constitutional Conference

- Policy Towards Poverty Reduction/ Alleviation - SMEDAN, PAP, SMSE etc

- Privatisation Policy

- Emphasis on Infrastructural Development etc.

The plethora of reforms, policies and programmes highlighted above as introduced by the administration were geared towards developing the country socio-economically and ensuring that Nigerians derive maximum benefit therefrom. The formulation of these policies and programmes is laudable, but the execution of most of them ended in fiasco. Nigerians were frustrated and made more impoverished. The challenges are legion, but we shall examine only a 
few considered to be the crux of the of the nation's governance crisis.

\title{
4. Corruption
}

One of those issues triggering governance crisis and democratic problems in the country is corruption. In Nigeria, corruption is rife and very endemic. It is afflicting and ravaging all sectors of the Nigerian state. All tiers of government are equally culpable. Obasanjo decried the effect of corruption on governance. According to him:

\begin{abstract}
No society can grow and develop when corruption is allowed to progress unfettered as it has grown into a cancer in Nigeria. Government and its agencies became thoroughly corrupt and reckless. Members of the public had to bribe their way through ministries and parastatals to get attention and one government agency had to bribe another government agency to obtain the release of their statutory allocation of fund. (Obasanjo, 1999).
\end{abstract}

To tackle this problem headlong, the first bill proposed by the Obasanjo administration after inauguration was the establishment of Independent Corrupt Practice Commission (ICPC) to fight corruption. The bill was sent to the National Assembly in July 1999 for a law to prohibit corruption and also punish public officers that engage in bribery, corruption and other sharp practices. To the utter dismay of Nigerians, the bill was not only watered down by the legislators for reasons of personal interest, it also took almost a year before it could be passed into law by both houses. Apart from this, the state governors challenged the legality of such a law. Infact, Abia and Ondo state governments went to court on this. The matter was laid to rest after a judicial pronouncement by the Supreme Court, affirming the constitutionality and legality of the laws, except two provisions that were considered unconstitutional (The Guardian, June 8, 2002). The seeming ineffectiveness of ICPC necessitated the establishment of Economic and Financial Crimes Commission (EFCC) by law in June, 2004. EFCC is responsible for the enforcement of all economic and financial crimes laws (Tell, June 13, 2005).

There is no doubt that the campaign against corruption in Nigeria has intensified since 1999. The establishment of the two aforementioned bodies in addition to the already existing Code of Conduct Bureau (CCB) is a clear indication of a serious drive towards a corruption-free Nigeria. But the question is, is the country free of corruption despite these bodies?

ICPC is an organisation that can be said to have been dead upon arrival. It is inactive, docile, weak and obtuse. It seems not to know its objectives and people's expectation from it. Evidently, the organisation can not lay much claim to the eradication of corruption in the country. At inception, the EFCC really showed commitment and desire to fight corruption. This perhaps may be due to the youthful and dynamic personality of the organisation's chairman- Nuhu Ribadu. Ribadu seemed passionate about fighting corruption, and under him, it can be said that the EFCC was effective, but highly controversial. It was controversial in the sense that it later became a potent instrument to intimidate and harass political opponents, particularly of the ruling party. Even Ribadu himself was sent away from the commission in a controversial manner. Nigerians had a perception of a focused, dynamic, no-nonsense and courageous commission, judging by its activities at inception. As such, the EFCC was receiving complaints and petitions from Nigerians daily, reporting the corrupt practices of their leaders and other compatriots. The morale of the people was dampened when, because of the usual "Nigerian factor", the majority of such petitions and complaints were swept under the carpet. However, the EFCC can still be credited for the arrest, prosecution and conviction of some people who were seen as untouchable in the country such as the former Inspector General of Police, Tafa Balogun, former governor of Bayelsa state, Chief D.S.P Alamieyeseigha and a host of others.

The corruption problem is unabated and persistent. It is stifling development and affecting governance. A respected Nigerian scholar, Rotimi Suberu, observes that the petty corruption that takes place ubiquitously in the country is conspicuously trivial compared to the monumental corruption that is orchestrated at the upper reaches of the country's society and polity (Suberu, 2009: 261). Suberu is saying the obvious. Nigerian newspapers are awash with gory stories of corruption across the length and breadth of the country. For example, over N14 billion was discovered in the personal accounts of those in charge of the Pension Scheme in the country (Daily Trust, 19th March, 2012). The pensioners the money is meant for are dying of hunger and penury. So many billions of naira was mismanaged by the Niger Delta Development Commission (NDDC) management, yet, the Niger Delta region for which the money is meant remains problematic as the people are poor and lack basic amenities. This led President Goodluck Jonathan to relieve all board members of their appointment over large-scale fraud on the award of contracts for projects in the restive region (Onyeose, 2011, This Day, 14 September, 2011). All sectors of the Nigerian state are affected. In the judiciary, most of the 2007 gubernatorial cases are still unresolved as so many judges were accused of bias and corruption. For example, 
the judgment at the Appeal Court Tribunals in respect of Ekiti and Osun states are still subjects of litigation and the governors concerned are still having legitimacy crisis. A president of the Court of Appeal, Hon. Justice Isa Ayo-Salami is suspended on $18^{\text {th }}$ August, 2011 by the Nigerian Judicial Council (NJC) for gross misconduct (Falade, Nigerian Tribune, Friday, 26 August 2011).

This has led to a chain of reactions involving litigations in various law courts bordering on the alleged bias in Sokoto, Ekiti and Osun states' 2007 gubernatorial Court of Appeal judgements. (Adewole cited in Nigerian Tribune, Friday 16 March, 2012). There is a judicial pronouncement that gave perpetual injunction that the tenure of Peter Odili of Rivers state should not be investigated by any agency or body of government, yet the people of that state are not seeing him as a clean man. A case is still in court against Kenny Martins and others, who were accused of siphoning N7.4 billion out of Police Equipment Fund. Police officers and the rank and file are without the necessary equipment to fight crime, partly because of large-scale corruption in the force. The nation and its citizens are at the receiving end, the education sector is in a shambles, the economy is comatose, electricity is epileptic, and the nation is in total decay because of corruption.

The issue of corruption is deep-rooted because of the tolerance of the political class of the cankerworm. It is obvious in the actions, utterances and body languages of the political class and elites generally that they are hostile to the anti-corruption war. Transparency is sacrificed and accountability is discounted. The culture of impunity has taken over the land, and over-invoicing, contract inflation, bribery, outright diversion and embezzlement of public money are the rule rather the exception. Assiduously, the political elites work towards statutory emasculation or constitutional invalidation of agencies responsible for fighting corruption.

\section{Leadership Challenges}

It will be out of tune to discuss governance crisis in Nigeria without examining the leadership issue which is central to governance and democratic development. Agagu (2004) provides an insight into the nature and character of leadership in Nigeria which can help us situate governance and democracy in the period under review. According to him;

The basic problem of democracy and development in Nigeria is the nature and orientation of the political actors as framed by the nature of the Nigerian state. The political actor either as a ruler or an opposition member is concerned with his self interest. He is less concerned with what constitutes the interest of the state. As a ruler, he is concerned with the survival of the system only to preserve his interest. Indeed as a ruler, he does not serve the interest of the state except when the state is seen as an instrument of oppression and exploitation. As an opposition member, he is concerned with how the system will collapse, not with how his criticisms will improve the system for preservation (ibid: 61-42).

The above is a true reflection of the Nigerian leadership. The leadership is self serving, greedy, corrupt and excessively wicked. The egregious leadership problems in the country can be seen in all sectors of the Nigerian state. Democracy presupposes leadership accountability to the people but the situation in the country is such that the 'leaders' are the 'masters' and therefore too big to render their stewardship to the people they claim to be serving.

Despite the fact that they are earning so much, they pay peanuts in form of salary and allowances to public sector workers. For example, the National Minimum Wage Bill was signed into law by President Goodluck Jonathan on March 2011, thereby raising the monthly minimum wage from N7,500.00 to N18,000.00. With the new act, it is now compulsory for all employers of labour in specified categories of establishments including the nation's three tiers of government to implement the law (Adeosun, 2011 National Mirror, 16 $16^{\text {th }}$ March : 1). Since then, the majority of the state governors are by their actions repudiating the law, or compromising its enforcement. Many have simply refused to pay the approved national minimum wage under the guise that their states cannot afford it. Workers in such states have downed tools to force these governors to pay, but the story still remains the same.

One of the problems associated with leadership in Nigeria is leadership recruitment. Most of these leaders were forced on the people by their various political godfathers, not on the basis of performance but for their ability to serve the interests of these godfathers. In most cases, they take advantage of the poverty ravaging the land to bribe their ways to power. The issue of godfatherism has made a mockery of the Nigerian governance and democratic experience. For example in Oyo State, the late Lamidi Adedibu held sway as he single handedly enthroned and dethroned governors and other political office holders. He told whoever cared to listen that he was the one that made Rashidi Ladoja governor of the state and equally removed him when he (Ladoja) became obstinate. According to Adedibu: 
... You (Ladoja) kept government away from me for 28 months? ... The government that, by the grace of God, I gave to you... I put him (Ladoja) there, so if I am demanding money, will it be wrong? Do I need to ask for it before he gives me? (Adedibu cited in Tell, 2006: 20-21, emphasis mine)

Godfatherism is threatening governance and democracy in Nigeria, frustrating the people and affecting the capacity of the government to develop the country. What should have been used for development is misappropriated to maintain and appease these godfathers. And the crisis this phenomenon engenders between the godfather and godson has been seriously dysfunctional to the stability and development of the state. For example, Kwara State, it was Saraki (godfather) versus Alabi Mohammed Lawal (godson/ governor); in Anambra State, it was Chief Emeka Offor (godfather) versus Chimaroke Mbadinuju (godson/ governor) and later, Chris Uba (godfather) versus Chris Ngige (godson/ governor); in Enugu State, Jim Nwobodo (godfather) versus Chimaroke Nnamani (godson/ governor); and in Kano state, the late Alhaji Abubakar Rimi (godfather) versus Rabiu Kwankwaso (godson/ governor); and so on and so forth.

These crises shook the various states to their foundations, polarizing the states along godfather and godson/governor camps, distracting governments and destroying governance. Most of the states concerned are without development projects that are commensurate with the quantum of resources available to them. Such resources were diverted, misappropriated and mismanaged to the satisfaction of the godfathers but to the detriment of the people.

\section{Ethnicity}

Ethnicity is equally an issue impacting on governance and democracy in Nigeria in the period under review. Shortly after the inauguration of civilian administration in 1999, various ethnic groupings in the country started to ventilate their pentup anger against the state for perceived injustice and marginalisation. The resultant effect of this was the proliferation of various ethnic militias championing ethnic agitation for a better deal in the Nigerian political system. In Yoruba land, there is Odua Peoples' Congress (OPC); in the North, Arewa People's Congress (APC); and in Igbo land, Movement for the Actualisation of Sovereign States of Biafra (MASSOB). In the South- South region, holding sway are ljaw Youth Congress (IYC) Bakassi Boys, Supreme Egbesu Assembly (SEA), Movement for the Emancipation of Niger Delta (MEND), among others.

In their operations, these ethnic militias went beyond mere agitation for the development of their various areas; they became violent and actually threatened the political stability of the Nigerian state, with many reported cases of violence orchestrated by these groups in various parts of the country. Though some of the activities of these groups were curtailed by the state, the truth of the matter is that in those instances they merely retreated underground to continue their violent agitations. The activities of these groups are dysfunctional and inimical to the democratic stability of the Nigerian state and dangerous to peaceful co-existence among its diverse people.

The problem of ethnicity manifested in who occupied which office. For years, the Hausa/Fulani and other tribes of the northern region had dominated the political leadership of the country, but in 1999, there was a change as a Yoruba man became the president as a result of a deliberate action to allow a power shift to the western region. The temporary loss of power by the Hausa/Fulani group created problem for democratic system. Shortly after this, there was allegation of bias against Obasanjo's government particularly on the appointment of service chiefs and other key officials. Alhaji Musa Yar'Adua took over from Chief Obasanjo after the expiration of his second term in office. However, Yar'Adua faced serious health challenges that finally led to his death. While he was in hospital, the nation lay prostrate, as nobody was in charge, with the then Vice President, Dr Goodluck Jonathan, disallowed from acting because of his minority status as an ljawman. This was so because of the north believed that the presidency belonged to them at that time, and therefore, nobody from outside the core north could act in the position. It took the intervention of the National Assembly which later came up with the "Doctrine of Necessity" before Dr Goodluck Jonathan was allowed to become the Acting President (Nigerian Tribune, 16 February, 2010). According to the Senate President, David Mark:

The Doctrine of Necessity requires that we do what is necessary, when faced with a situation that is not contemplated by the constitution. And that is precisely what we have done today. In doing so, we have maintained the sanctity of our constitution as the ultimate law of the land (Mark cited in Nigerian Tribune, 16 February, 2010).

He was later sworn in as the president after the demise of Alhaji Musa Yar'Adua. The declaration of Dr Jonathan, an ljaw man from the Niger Delta, to run for the presidency in the 2011general election brought about tension in the country. Adamant that nobody must take what "belonged" to them, the northern elites came under an umbrella organisation known as Northern Political Leaders Forum (NPLF) under the chairmanship of Mallam Adamu Ciroma, 
whose sole mission was to see that a northerner emerged as the candidate of the ruling Peoples' Democratic Party (PDP) and occupied 'Aso Rock,' the seat of the national government eventually. The group screened various presidential aspirants in the north and came up with Alhaji Atiku Abubakar to slug it out with Dr Goodluck Jonathan at the party's primary. Meanwhile, the Niger Delta elite did not lie low in all these. They also came together under the leadership of Chief Edwin Clark and threatened that it must be Dr Jonathan or nothing because they were not slaves in Nigeria. In fact, the ljaw leader, Edwin Clark, addressed an open letter to NPLF entitled "Adamu Ciroma, Your Utterances Will Lead to the Disintegration of Nigeria," describing their moves to frustrate Jonathan's presidential ambition as an exercise in futility (http://ireports-ng.com) All these debates heated up the polity. Eventually, Dr Jonathan was declared the winner of the PDP presidential primary and later the general election. Since his assumption of office, the country, particularly in the northern region, has not witnessed peace. This is as a result of the activities of Islamic fundamentalists known as Boko Haram (which means Western education is a sin). The group claimed responsible for the bombing of various public targets including places of worship, the United Nations (UN) building, the Nigeria Police Headquarter building in Abuja, and even primary schools.

Keen observers of Nigerian government and politics have linked Boko Haram's activities to the events, before, during and perhaps after the 2011 presidential election, arguing that these activities are part of an agenda to make the country ungovernable for Dr Goodluck Jonathan who is not from the 'right ethnic group' and should therefore occupy Aso Rock. In these circumstances, there is no doubt that Nigerian democracy is facing a major threat. The people of Niger Delta have warned that nothing untoward must happen to their son.

Ethnicity thus remains a major threat to national stability as Nigerians find it too difficult to rally round a leader to develop a strong, dynamic and virile nation.

\section{Insecurity}

Insecurity is another major problem to governance and democratic stability in the country. As noted earlier, the enthronement of a democratic system in 1999 led to the ventilation of pent-up anger by various groups. This is coupled with political issues in which various groups, expressing grievances more stridently than ever while at the same time positioning themselves for better economic and political opportunities. All that were impossible under the .military are now brought to the fore because of democratic rule which emphasises rule of law and enthronement of fundamental human rights. Adebanwi amplifies this by noting that;

The constriction of the democratic public sphere for several years, under the military prevented various interest groups and social and political formations from advancing their interests and expressing their grievances through democratic means. When democratic rule was achieved, these interests and grievances burst forth with speed; gushed forth like an overflowing dam whose boundary walls have been brought down on a still-limited democratic space, producing the conflagration which we are witnessing (Adebanwi; 2004: 328)

The ventilation of pent-up anger by various groups in the country has aggravated the insecurity situation far beyond the capability and capacity of the Nigerian security forces. What makes the matter worse and deep rooted is the unemployment problem. With over 70 percent of the Nigerian youths either unemployed or underemployed, it is easy for the elite to recruit the already frustrated youths to fight their political and economic interests/ battles. Since 1999, the country has witnessed political, ethnic, economic, religious, electoral crises that have almost consumed the nation. Some of the violent communal or ethnic conflicts include:

Zango-Kataf in Kaduna state; Tiv-Jukun in Wukari, Taraba state, Ogoni-Adoni in Rivers state; Chamba-Kutub in Taraba state; Itsekiri- Ijaw/Urhobo in Delta state; Aguleri-Umuleri in Anambra state; Yoruba-Hausa community in Shagamu, Ogun state; ljaw-Ilaje conflict in Ondo state; the intermittent clashes in Kano, Kano state; BassaEgbira in Nasarrawa state; Eleme-Okirika in Rivers state; Hausa/ Fulani- Sawaya in Bauchi state; Fulani- Irigwe and Yelwa-Shandan both in Plateau state; and the Hausa-Yoruba clashes in Idi-Araba, Lagos state (Imobighe; 2003: 13-14).

Violence characterised various elections in Nigeria since 1999 as parties allege rigging and intimidation. One of the noticeable insecurity issues in the land is political assassination which is rife as a way of settling political scores. So many politicians lost their lives to assassins since 1999, and the police are unable to trace their killers. According to Shehu Sani (2007), some of the affected politicians include the following:

Odunayo Olagbaju, a member of Osun State House of Assembly; Olayiwola Lawrence, Chairman of Alliance for 
Democracy $(A D)$ in lle-lfe, Eze Odumegwu Okonkwo, ANPP leader in Nnewi, Anambra state; Chief Bola Ige, AD stalwart and also the then Attorney-general and Minister of Justice in PDP's government; Harry Marshal an ANPP chieftain, Aminosari Dikibo, National Vice chairman (south-south) of the PDP, Chief Andrew Agom, Member Board of Trustees PDP, Hajia Saadatu Rimi, wife of Abubakar Rimi, former PDP chieftain in ACD... Jesse Anukwu, Funsho Williams and Ayo Daramola, all three of them being gubernatorial aspirants for the 2007 elections (Sani; 2007: 126127).

The case of Chief Bola Ige is particularly intriguing. As at the time of his assassination, he was the nation's Attorney-General and Minister of Justice, whom Nigerians thought should have been impossible to assassinate easily because of security details attached to him. Even at that, after the assassination, it is felt that his killers should have been apprehended but up till today, nobody has been caught. This singular case and many more give the Nigeria Police out as a weak, inefficient, ineffective and corrupt-ridden organisation. The new Acting Inspector General of Police (IGP), Mohammed Dikko, amplifying this view in his recent meeting with the senior police officers he noted that:

\begin{abstract}
Police duties have become commercialized and provided at the whims and caprices of the highest bidders. Our police stations, state CIDs and operation offices have become business centers and collection points for rendering returns from all kinds of squads and teams set up for the benefit of superior officers. Any observed non -compliance to these directives and subsequent ones which shall be issued from time to time will attract severe sanctions as my administration will not be frustrated by officers' noncommittal attitude to work nor will it tolerate indiscipline, indolence, corruption, inefficiency and all the negative tendencies that have brought so much disgrace to the force. (Mohammed cited in Ewepu, 21 March, 2012)
\end{abstract}

As a result of his observation, he ordered the dismantling of police check points across the country which he said has become a centre of extortion of motorists. I think the Acting (IGP) is trying to clear the Augstean stable knowing full well the politics that brought him to office. The inability of the Nigerian police force to curtail Boko Haram insurrection and coupled with the disappearance of one of the leaders of this deadly organisation, Kabiru Sokoto from police cell led to the removal of the former (IGP).

It is a known fact that members of the Nigeria Police Force are weak and corrupt, but, can they be totally blamed for this? The force is without necessary crime-fighting equipment and officers and men are not well-motivated in terms of salary, allowances and other welfare packages. Armed robbers are on the prowl on the Nigerian roads, banks are attacked without restraints, and houses are ransacked at will. Nowhere is safe in the country any more. It is very risky to travel in broad daylight and suicidal in the night because of men of the underworld. Then how can we achieve democratic stability and good governance with all these anomalies?

Governments in Nigeria have always indicated their commitment to good governance. But in reality, this is nothing more than lip service and mere window dressing because excessive poverty and infrastructural decay still pervade the length and breadth of the country. Despite allocation from the Federation Account to the various states and local governments, there are virtually no developmental projects to show for it. The roads are terribly in bad shape, water taps are perpetually dry, electricity is quite irregular, hospitals are without necessary medication, schools are grossly underfunded, and in fact, virtually all sectors are neglected by the country's political leadership. Ordinarily, the democratic system should usher in good governance and bring the citizens the proverbial dividends of democracy. Brinkerhoff and Brinkerhoff (2002) observe that: "When governance systems break down or are destroyed, the door is opened to instability, oppression, conflict and unchecked political and economic opportunism" (Brinkerhoff and Brinkerhoff; 2002: 511). The observation of Brinkerhoff and Brinkerhoff above is particularly relevant to Nigeria, where governance systems have certainly broken down. This has led to the unrelenting clamour for Sovereign National Conference by various nationalities despite the fact that these nationalities have representatives in the National Assembly and other government organs. Fueling the agitation are the lack of faith in these representatives and the perception of the people that those in government are weak, greedy, inefficient, ineffectiveness, corrupt and incapable of engendering good governance. note that;

Commenting on democratic governance and the need to engender development Brinkerhoff and Brinkerhoff (ibid)

Democratic governance mechanisms include selection of political leadership through elections, accountability and integrity system, conflict resolution and consensus building, institutions and procedure. Democratic governance addresses social equity and inclusiveness, management of diversity, broad based legitimacy and protection of vulnerable groups (Brinkerhoff and Brinkerhoff, ibid: 512)

In other words, good governance and democratic stability call for active participation of all citizens in the political 
process. The situation in the country since 1999 has not really given room for citizens to freely choose their leaders/ representatives. Such leaders/ representatives are in most cases imposed on the people by godfathers and other interests. Political leaders take advantage of excessive poverty in the land to buy citizens' vote. During election, voters are induced by money to vote for a particular candidate. In most cases, the highest bidder gets the competitive position. It is fashionable in the country for politicians not to bother themselves with selling their candidature to the people through campaign, radio and television programmes and features but rather concentrate on amassing money in local and foreign currencies. Party primaries are manipulated at will to favour particular candidates, and the conduct of local government election is worse. The governor of each state always constitutes the State Independent Electoral Commission (SIEC) charged with the conduct of local government elections. Little wonder, the typical experience is that the party in power in the state always wins all chairmanship and councillorship seats in such elections. A case in point is the last Lagos State local government election conducted recently. The PDP accused Lagos SIEC of manipulating the election to favour the ruling ACN. According to the PDP, despite the fact that the result of the election was known at the various polling centres as declared by the officials which gave the party the opportunity to know the local governments won by it, LASIEC went ahead and manipulated the result. The Nigerian Tribune in its Wednesday $9^{\text {th }}$ November, 2011 editorial condemned the action of LASIEC. It is necessary to quote the editorial at length for purpose of clarity and thorough understanding of the issue,

The Lagos State Independent Electoral Commission (LASIEC) is now in the eye of the storm, following the declaration of the Action Congress of Nigeria $(A C N)$ as the overall winner of the last local government election in Lagos State. Ordinarily, the protestation and complaints of the declared losers in this election could have been regarded as part of the traditional rigmaroles of politically-vanquished individuals, but the cogency of the issues raised by the affected losing parties makes the controversies that have trailed the conduct of the Local Council election in Lagos State a subject of keen debate and thorough scrutiny

... The allegation of rigging, ballot box snatching, intimidation and alteration of figures which has been levelled against LASIEC and by extension the Action Congress of Nigeria (ACN), by other participating parties and even neutral observers should be a source of embarrassment, not only to the State's electoral body but also to the ACN which has always prided itself as an apostle of electoral purity.

For instance, the Chairman of LASIEC has maintained a studied taciturnity on the damning allegations that he announced the results in the Commission's office in Yaba on Monday evening, thereby violating section 5(1)-8 of LASIEC law which stipulates that results should be announced at polling units or collation centres.

As directed by LASIEC itself, some results which were declared at the collation centres were upturned by the electoral body. For example, the election results in Badagry Local Government, according to reports, were announced by the returning officer, Mr. Tokunbo Fatoyinbo in conformity with section 5(1)-8 of the LASIEC Law, where the Peoples Democratic Party (PDP) candidate, Tobi Dada scored 7,353 votes to defeat the incumbent ACN Chairman, Hustode Moses, who scored 6,383 votes. To the chagrin of many discerning and even casual observers however, the Chairman of LASIEC, on Monday reversed the result and declared Mr. Moses as the winner of the election. This allegation of fraud, coupled with other electoral manipulations levelled against LASIEC by the opposition parties should, in the interest of democratic spirit be investigated to unearth the truth. Keeping mute can only bring to question, the credibility of LASIEC and even soil the image of Action Congress of Nigeria (ACN) itself.

The beauty of democracy is the opportunity it affords the competitors to either win or lose with the sovereign voice of the electorate through their votes. A situation where the will of the people has become endangered with the alteration of election results and bare faced intimidation is visibly anathema to the spirit of democratic norms and values. (Nigerian Tribune, Editorial, November 9, 2011)

In Ekiti state, Hon Justice John Adeyeye of the State High Court ordered the sack of the Chairman of the Ekiti State Independent Electoral Commission, Mrs. Cecelia Adelusi, and four commissioners on the board based on the PDP proven allegation that they were card-carrying members of the ruling Action Congress of Nigeria (ACN), contrary to constitutional provisions (Makinde, The Punch February 11, 2012 ). This was barely 48 hours to election, and the election was accordingly shelved in tune with the court pronouncement, but the state government swore in all the ACN candidates in the local government election to the various .positions they were vying for as caretakers. Is this political rascality and uncommon footworks not a mockery of democracy?

Failure of government institutions constitutes a threat to good governance in Nigeria. The organs of government are weak and inefficient; the executive is lawless, evasive and uninterested in citizens' welfare and development; the legislature is greedy, inconsiderate and indifferent to citizens' pitiable conditions; while the judiciary is crisis-ridden, corruption-prone and incapable of being the last hope of the common man. Where does the nation go from here? Because of the failure of government institutions, people in most cases have resorted to self- help and accommodation 
within ethnic nationalities. The upshot is promotion of ethnic agenda, militancy, agitation and gang-up against the Nigerian state. Governments at all levels are incapable and unable to perform their statutory function of protection of lives and property. The view expressed by Fotopoulos (1997) put this in perspective. According to him;

Today, increasing numbers of people do not have access to the political process (except as voters), to the economic process (except as consumers) or the environment ...thus, at the political level, it is the elite or professional politicians who take all significant political decisions. Similarly, at the economic level, what is produced in a country is not determined by the democratic decisions of its citizens but by property relations and the income distribution pattern. Finally, the sort of projection the environment is entitled to have effectively determined by the political and economic elites which (sic) control the market growth economy (Fotopoulos; 1997: 132-133).

It is important to note that the country is stagnated for years because of weak and inefficient governments at all levels. The failure of government is pervasive, obvious and rife. It is noticeable in virtually all areas of the economy, public transportation is in a shambles, and public service is inept, slow, lethargic, conservative and incapable of delivering services to the citizens. Haque and Aziz (1998) attribute the problems to comprador elements or rent-seeking elites that undermine markets and see the public sector as a means of delivering employment patronage. If merit is sacrificed on the altar of patronage, how can we come about quality, efficiency and effectiveness in the nation?

\section{Conclusion}

Democracy is adjudged the best form of government in the world today because of its attribute and the perception of allowing effective citizens participation in governance, transparency and accountability.

In this chapter, we have examined the Nigerian democratic project since 1999. It is observed, that though during this period democratic institutions have been put in place, the people have not really enjoyed the well known dividends of democracy.

We have also attempted to draw out the challenges confronting governance and democracy in the country to include weak governmental structures, inefficient public service, corruption, ethnicity, godfatherism, monetisation of politics, and political violence.

It is necessary to note that the democratic process should be universal and the characteristics should be the same all over the world. As such, it will be inelegant for Nigeria to have its own brand of democracy. In other words, Nigeria should key in or imbibe universal democratic norms and inculcate its ethos and tenets in the minds of its citizens. Both the leaders and the led should allow democracy to be operated in the country just as in other civilised nations in order to enthrone good governance, accountability and transparency at all levels and in all sectors of national life.

It must be emphasised that in Nigeria today there is pervasive and biting poverty. Therefore, for democracy to engender good governance there is the need for massive infrastructural development across the country in the areas of road, electricity, pipe borne water, and so forth. In addition, issue of poverty eradication must be addressed frontally. Governments at all levels must also exhibit budgetary discipline. Budget in the country is gradually becoming an annual ritual without any effect on government's revenue and expenditure profile. Also, there must be a need for strengthening the legislative arm of government, so as to effectively and efficiently perform its assigned responsibilities, particularly its oversight functions, to put the executive on its toes in its service delivery functions. Furthermore, legal and electoral reforms should be carried out, to do away with defective aspects as well as promote good governance. Sectoral service delivery and capacity building are equally essential to empower and strengthen sectors such as health, agriculture service, education, trade and industry, and so forth. Without these sectors optimally performing their roles, good governance may be difficult to achieve. The officers in charge of these sectors must be mobilised, motivated and trained to enable them rededicate themselves to the service of the state.

Civil society actors also must be alive to their responsibilities, particularly as the bulwark against corruption, inefficiency, ineffectiveness and general maladministration. Citizens as well must be well mobilised to always demand accountability and transparency from their leaders

\section{References}

Adebanwi, W (2004) "Democracy and Violence in Nigeria: The Challenge of Communal Clashes" in Adigun Agbaje et al (eds) Nigeria's Struggle for Democracy and Good Governance: A Festschrift for Oyeleye Oyediran, Ibadan: University Press

Adedibu. L. (2006) cited in Tell, January 23, No 4

Adeosun, O (2011) "President Signs National Minimum Wage Bill" in National Mirror, 16th March 
Adesanmi. A (2012) "Pension Officials Diverted =N= 45 Billion Police Fund" in Nigerian Tribune, Ibadan, March 8

Adewole, L. (2012) "Rumbling in the Judiciary: The Politics, the Intrigues" in Nigerian Tribune, 16 March, 2012

Ajayi. A (2012) "Ogun Workers Threaten Strike Over =N=18,000 Minimum Wage" in Nigerian Tribune, Ibadan, March 8.

Brinkerhoff. D.W \& Brinkerhoff. J.M (2002) "Governance Reforms and Failed States: Challenges and Implications" in International Review of Administrative Sciences 6, 8

Daily Trust (2012) 19th March,

Ewepu, G. (2012), "Nigeria: How Police Lost Their Cake" in Leadership, March 21

Falade, D (2011) "The Man in The News - Ayo Isa Salami: A Judge and His Many Controversies" in Nigerian Tribune. Friday, 26 August

Fotopolous, T. (1997) Towards an Inclusive Democracy: The Crisis of the Growth Economy and The Need For a New Liberatory Project, London and New York: Cassell

http://ireports-ng.com, (2011) "ljaw Leader, Edwin Clark Spits Fire, Blasts Ciroma Over 2011"

Imobighe, T.A (2003) Civil Society and Ethnic Conflict Management in Nigeria, Ibadan: Spectrum Books Limited

Makinde, F (2012), "Scuttled LG Poll Creates Tension in Ekiti" in The Punch, February 11

Nigerian Tribune (2011), "The Lagos Lg Elections" in Editorial Wednesday, 09 November.

Obasanjo, O. (1999) "Presidential Inaugural Speech" on May 29, 1999 in The Guardian, May 30

Onyeose, C. (2011) "GEJ Sacks NDDC Board" in Daily Times, September 14

Sani Shehu (2007) Political Assassinations in Nigeria, Ibadan; Bookcraft

Suberu. R. T (2009) "The Travail of Nigeria's Anti- Corruption Crusade" in Robert I. Rotberg (ed) Corruption, Global Security and World Order, Cambridge: World Peace Foundation

Tell (2005) June 13

The Guardian (2002) June 8

This Day (2011) September 14 